Jurnal Ilmial

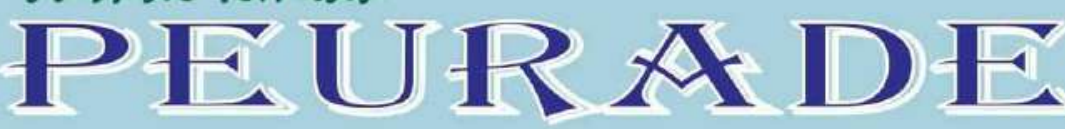

Vol. 5, No. 1, January 2017

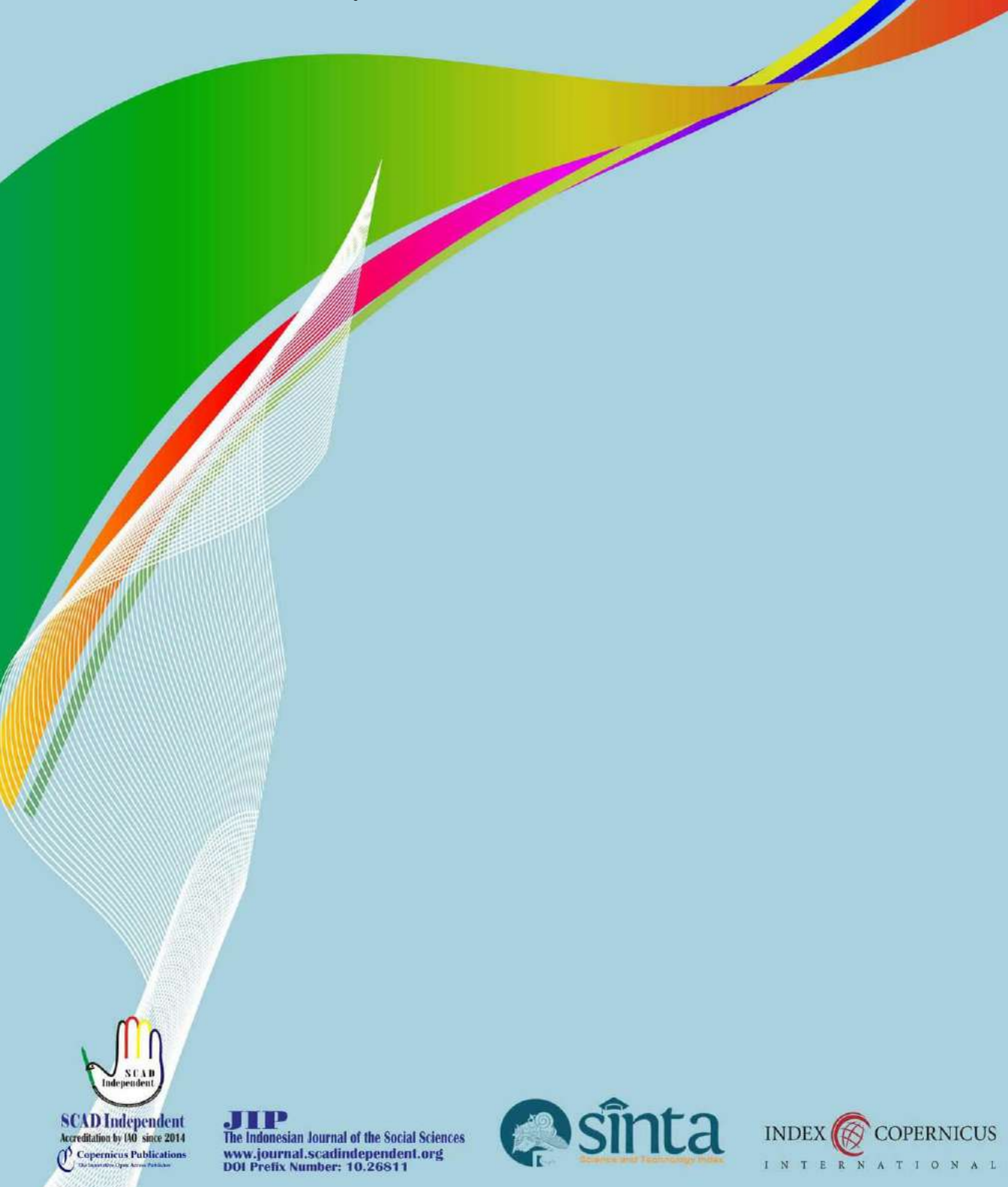




\title{
LAW PART OF THE FRAMEWORK FOR ACCOUNTABILITY IN POLICY INTERPRETATION AND PRACTICE
}

\author{
Vanessa Abbasi ${ }^{1}$ \& Karolina Marzieh ${ }^{2}$ \\ 1,2University of Nottingham, United Kingdom \\ ${ }^{1}$ Contibutor Email:vanessaabbasi@nottingham.ac.uk
}

Received: Aug 30, 2016

Accepted: Sept 13, 2016

Published: Jan 28, 2017

Article Url: http://journal.scadindependent.org/index.php/jipeuradeun/article/view/122

\begin{abstract}
Law can increasingly be seen as part of the framework for accountability in policy interpretation and practice. This is reflected in important judgments in the UK and European context, where courts have been proactive in challenging restrictive interpretations by agencies of their legal duties, or even by parliament in law-making that is incompatible with the European Convention on Human Rights and Fundamental Freedoms. Without attention to the practice environment for legal and ethical practice, the role of law in welfare reform will be compromised, however robust the legal framework. Subsequently, empirical work has explored how social workers learn about the law, in both practice and academic environments, and how they use that learning. This paper considers the complex relationships between law, welfare policy and social work practice, to address the question of what role legal frameworks might play in achieving welfare policy and professional practice goals. These debates illustrate is the essentially contested nature of the relationship between law and practice and the delicate balance between law and ethics within a framework for professional accountability. It is hardly surprising, perhaps, that law is often seen by practitioners as alien and hostile territory.
\end{abstract}

Keywords: Law, Accountability, Transformational, Practice, Legal Frameworks 


\section{A. Introduction}

In some national jurisdictions, law is seen as one of the core mandates for social work practice, with some in the UK context claiming that it is the core mandate (Braye and Preston-Shoot, 1997). In contrast to this emphasis on the centrality of law, others (for example, Stevenson, 1988) have claimed a different core mandate - that of an ethical duty of care, in pursuit of which social workers might use the legal framework as one of the tools of their practice.

This position is certainly more apparent in North American literature (Dickson, 1997; Madden and Wayne, 2003; Watkinson, 2001), and retains a strong currency across a range of national contexts, acting arguably as a counterbalance to the dominance of legal rules. It is not uncommon, however, when welfare reform is on the agenda, for the law to be seen as a critical component in developing provision and strengthening professional practice. In the UK context, the centrality of law has developed over time, fuelled by a series of high profile events within child care, public responses to which were characterized by a perception of flawed professional practice in relation to the legal mandates for protecting children.

Inquiry into the death of Victoria Climbie (Laming, 2003), who died in circumstances that must be amongst the most shocking in terms of child cruelty, concluded that it was the welfare system management, administrative and supervisory systems that had failed her. The answer now proposed in the Children's Bill of 2004 is to create a legal and administrative system for sharing of information and surveillance of children in the UK that is certainly unprecedented and has been critiqued as a gross invasion of both parents' and children's human rights (Garrett, 2003). No doubt the intention is to make sure social workers and others concerned with children's welfare get it 'just right.

These examples demonstrate the conflicting imperatives that are juxtaposed in welfare legislation, and which policy-makers must reconcile in the legal rules. State interventions may be designed both to protect and to support citizens, oscillating between paternalism, respect of individual autonomy and a search for empowerment. Social workers must balance these imperatives in each case they encounter, navigating the practice dilemmas that ensue. 
These debates illustrate is the essentially contested nature of the relationship between law and practice and the delicate balance between law and ethics within a framework for professional accountability. It is hardly surprising, perhaps, that law is often seen by practitioners as alien and hostile territory. Students are fearful of learning the law, identifying it as 'not social work', although they recognize their practice will be inherently bound up with it. It is construed as something that creates tensions and dilemmas in practice, gets in the way of, or spoils, relationships with service users, or a big stick with which social workers will be beaten when they go to court (Braye and Preston-Shoot, 2005). Kennedy with Richards (2004) notes, that negative reactions of this kind are sometimes driven by emotion rather than objective assessment, and argues for practitioners to develop a more strategic relationship with law and legal systems.

The recognition of these complexities has informed theory development and research in law and social work over the past fifteen years in a number of jurisdictions. Such work has sought to address how both law and an ethical duty of care, if both provide mandates for professional activity, are connected in practice; and how might practitioners negotiate the interface between them, responding to any tensions and dilemmas that might arise. Subsequently, empirical work has explored how social workers learn about the law, in both practice and academic environments, and how they use that learning.

\section{B. Relationship between Law and Social Work Practice}

1. Law Provides a Clear map for Welfare Practice

This assumption is displayed when things go wrong in practice and people, usually children, get hurt. It underpinned the harsh criticisms of social workers' legal knowledge in the UK in the 1980s, and is perhaps most graphically illustrated recently in the report of the enquiry into the death of Victoria Climbié. Beneath the criticisms of individual professional practice and collaborative inter-agency practice (Reder et al., 1993) lies an unquestioned assumption that the legal framework for protecting children is in itself sound. There are a number of problems with this position.

There is in fact no one legal map relating to professional practice, but a series of maps. Law is drawn from a range of sources - statute, court decisions, 
codes of practice, policy and practice guidance. Practitioners need a whole bag of legal maps, because no one alone shows the whole legal framework. Statute, as one legal map, is constantly being redrawn, either by itself as when one Act repeals or develops another, or by judicial decisions and government guidance. For example, in the UK judicial concern that local authorities were insufficiently accountable for how they delivered care plans for young people resulted in the Adoption and Children Act 2002, amending the Children Act 1989 to create a route back to court to review the outcome of care orders. Courts have caused mental health law to be redrawn so that it is compatible with the European Convention on Human Rights and Fundamental Freedoms in respect of when a same gender partner may act as a nearest relative and when an approved social worker must consult a nearest relative. Government guidance on assessment of children in need and disabled people is essential for finding direction in child care and community care practice.

Equally, courts can find a mandate that does not exist in statute. They may use their inherent jurisdiction, and social workers may use the doctrine of necessity in the short term, to safeguard and promote the welfare of an adult who lacks capacity. Yet judicial influence on welfare policy and practice is often ignored, at the expense of statutory and executive influences (Alexander, 2003). This is a serious omission, when law can be a powerful tool with which to hold the state accountable for its actions towards its citizens, and can support practitioners in challenging oppressive state interventions towards service users or claiming rights that are being denied.

The arrival of new maps will have significant impact on how practitioners and their managers journey across the terrain. Finally, the clarity of the map is also compromised because some features, some aspects of law, are more detailed than others.

2. The belief that the legal map is the only one practitioners need

The legal map is not the only one in the backpack. Tucked into another pocket is the "ethical duty of care" map, showing professional values that may contradict what is legally mandated, or at least be tangential to it (Alexander, 2003). Where the legal map shows a mountain, here may be a valley, or an 
opposing contour. In respect of asylum and immigration policies, for example, social workers may wish actively to oppose legal rules that deny people access to such fundamentals as housing and social security (Humphries, 2004).

Other factors intervene in the map reading process. In an adversarial court system such as in the UK, the principle of welfare can become secondary to the quality of evidence and the quality of advocacy that is entered. Writers in both the UK (King and Trowell, 1992) and the US (Madden and Wayne, 2003) point to how legal processes can lead to harmful or anti-therapeutic outcomes, with social workers having to weigh this in the balance when considering intervention in people's lives.

Moreover, some territory hasn't been mapped at all. The profile of law differs between practice contexts. A practitioner charged with the responsibility of compulsorily detaining a distressed person in psychiatric hospital will identify without any difficulty their mandate in law. A practitioner in post-adoption counseling may not look to law at all for theirs.

Finally the map is not always available when it is needed. Even if practitioners are exceptionally well-equipped with the latest version, the weather can change, the mist comes down, it gets dark, the torch runs out, and the expedition loses its bearings. It is unwise to be without back up equipment compasses, flares, wet weather gear, energy food, survival kit and other ways of staying safe. Thus practitioners must have principles and practice wisdom to help navigate the challenges of the unexpected. As Kennedy with Richards (2004) points out, practice is located within interacting layers of contextual and often contradictory factors, of which law is only one.

\section{Use of Law by Practitioners}

In the approach characterized by technical rationality, legal knowledge is the driving force for practice. Emphasis is placed on practitioners having technical knowledge of the 'nuts and bolts' of the legal framework, of the powers and duties that are contained therein. The skills prioritized are those of applying that knowledge deductively to situations encountered in practice. Values are implicit rather than explicit here, and are likely to be construed as broad principles that underpin 
practice, such as 'working in partnership with parents', 'listening to children' or 'respecting human rights'.

In the approach characterized by morality and ethics, the search for ethical practice is the driver for professional activity. Legal rules are set alongside ethical rules, in pursuit of the exercise of a professional morality in any given situation. The question becomes that of determining the 'right' thing to do in moral terms. If there is no clear answer (as will often be the case in practice), the skill lies in determining the relative merits of different options, balancing the competing imperatives and dilemmas of practice, using ethical principles as guides in this task. Within this approach, law may at times be framed as antithetical to social work values, requiring hostile action to impose solutions that may challenge professional values. However, it is also possible to identify areas of convergence between values in social work practice and the legal rules (Preston-Shoot et al., 2001).

In the approach characterized by an emphasis on human rights, service users are the drivers of professional activity, from a starting point that social work's core function is to promote social justice and human rights (IASSW, 2001). Knowledge of the law might be much more broadly construed, to include not only the duties and powers that direct social work intervention it self but also the frameworks for challenging inequality and injustice, securing resources and building collective capacity. Skills prioritized are those of consultation, working in partnership, advocacy. The key question becomes that of how power might be balanced more equitably in any given situation.

Practitioners engaged in promoting rights need to know the technical aspects of the law. Law has a key role in regulating the use of power, and technical knowledge of administrative law is important in any professional decision-making process. Moral/ethical codes are inherently bound up with rights, or with notions of their curtailment. Legal duties must be accurately weighed in the balance with moral ones. Rational/ technical practice without structural awareness, whilst 'correct' in an administrative sense, will restrict social work to individualized interventions rather than collective agendas.

In order to understand the role of law in welfare provision, it is fundamentally important to explore how it is that social issues and concerns do 
or do not become framed as legal rules. In the UK context, for example, there is a detailed and unified statutory framework for child welfare, in terms of providing services to support families and protect children. By contrast, there is no coherent statutory provision for intervention to protect adults from abuse.

There are key questions to be posed when considering what kind of law to have. These are core philosophical and jurisprudential debates with which every jurisdiction must grapple (Kennedy with Richards, 2004). What kind of society do we want? Should issues be placed within a framework of "criminal" provision, or should "welfare" be the ruling ethos? Taking youth justice as an example, policy and law in the UK has vacillated between the two for many years and arguably failed to find a balanced position. Where "need" arises as a result of factors that are inherent within the structures of society, for example child poverty or racial discrimination, should state intervention be made on an individual or collective basis? Current UK frameworks for social work practice more clearly mandate the former than the latter. Should social workers have a legal duty to support community capacity building, or merely to pick up the pieces when individuals experience difficulties? Again in the UK the legal system responds predominantly on the individual level, leaving social workers to look elsewhere for inspiration to engage with the broader context of service users' lives. Nevertheless, some ways forward can be identified.

First, there needs to be a stronger articulation, debate and dialogue about what it is we want law to achieve, and therefore about the relationship between law and practice. The debate needs to move beyond the assumptions identified earlier, which obscure the complexities of the relationship, to tackle the core questions of how society should respond to welfare needs and rights. The dialogue and debate needs to involve as wide a stakeholder network as possible, and certainly to include practitioners, professional associations and service users. Whilst different groups will not always agree, there are constructive alliances that can develop to give clear messages to politicians. Those drawing the maps need intelligence from those working on the ground, and from those whose needs and rights are to be addressed through legally-informed practice.

Second, drawing upon the model outlined in Figure One above, the legal framework must allow for flexibility in the framing of 'problems', to give 
practitioners scope to respond in ways that are not constrained by individual models of intervention, but can address collective concerns also. Practitioners must have knowledge of such mandates, where they do exist. For example, in the UK, the Race Relations (Amendment) Act 2000 requires public authorities to work towards the elimination of unlawful discrimination and to promote equality of opportunity and good race relations.

They must not discriminate, directly or indirectly, in the performance of their duties. The approach to law, at both practice and policy level, needs to move beyond the 'rational/technical' model, certainly to recognize the moral/ethical dimension of managing its relationship with the legal mandates, and ultimately to embrace a more rights-based approach. This is not to downplay the importance of a soundly constructed technical framework and practitioners' knowledge of it - this would be dangerous, a little like setting out on a major expedition but leaving one of the maps in the cupboard at home. Nevertheless, in developing law that is fit for purpose, knowledge from other sources provides a range of filters or lenses that may be used by policy makers and practitioners to subject the legal framework to critical appraisal. There is increasing recognition that the sources of knowledge in welfare provision and professional practice are complex (Pawson, et. al., 2003), and that effective frameworks and interventions draw upon service user and career perspectives and practice wisdom, as well as research evidence and theory.

Third, it is important to build social workers' confidence in the legal arena, and to encourage them to see law as a positive tool. Service users comment that practitioners are ill-at-ease in legal systems, not confident of their place (Braye and Preston-Shoot, 2005). They wish to see lawyers and social workers as allies in the endeavor of securing rights and justice, not as adversaries. This has implications for the kinds of knowledge that practitioners need. It means a focus on aspects of law that empowers or promotes rights as well as upon those that coerce and constrain. Anti-discrimination legislation, human rights law, housing and employment provision, are arguably as important to social work practice as the aspects of law that allow compulsory admission to psychiatric hospital, or removal of a child at risk. A more balanced focus would enable practitioners to work alongside both service users and lawyers to secure goals that are important to service users. 


\section{Conclusion}

Without attention to the practice environment for legal and ethical practice, the role of law in welfare reform will be compromised, however robust the legal framework. This means developing practice structures that connect social workers and lawyers, teachers, health care workers. It means engaging in legally-informed debate in agencies, working to remove some of the constraints that are experienced by professionals working in corporatized welfare. It means creating structures for service users as stakeholders to articulate clearly their needs and rights in relation to the goals of professional practice.

Law can increasingly be seen as part of the framework for accountability in policy interpretation and practice. This is reflected in important judgments in the UK and European context, where courts have been proactive in challenging restrictive interpretations by agencies of their legal duties, or even by parliament in law-making that is incompatible with the European Convention on Human Rights and Fundamental Freedoms. With knowledge of this, practitioners can legitimately look to law for support in ensuring that their own and their employers' practices remain embedded within a duty of care that observes both legal and ethical rules. The benefit of recognizing this duality, and establishing equilibrium between technical knowledge, ethics and rights, is perhaps best reflected by a comment from a service user participating in the recent study of law in social work education.

\section{Bibliography}

Alexander, R. (2003) Understanding Legal Concepts That Influence Social Welfare Policy and Practice. Pacific Grove, CA: Thomson Brooks Cole.

Braye, S. and Preston-Shoot, M. (1997) Practising Social Work Law (2nd ed). London: Macmillan.

Braye, S. and Preston-Shoot, M. (2005) 'Practice Survey', in Braye, S. and PrestonShoot, M. with Cull, L-A., Johns, R. and Roche, J. (2005) Knowledge Review: Teaching, Learning and Assessment of Law in Social Work Education. London: Social Care Institute for Excellence. 
Braye, S. and Preston-Shoot, M. with Cull, L-A., Johns, R. and Roche, J. (2005) Knowledge Review: Teaching, Learning and Assessment of Law in Social Work Education. London: Social Care Institute for Excellence.

Dhuhri, S. (2016). Art as A Cultural Instrument: The Role of Acehnese Art in Resolving Horizontal Conflict. Jurnal Ilmiah Peuradeun, 4(1), 89102.

Dickson, D. (1997) 'Law, ethics and social work with the elderly: selfdetermination', Journal of Law and Social Work, 7(2), 105-125.

Garrett, P. (2003) 'The electronic eye: emerging surveillant practices in social work with children and families', European Journal of Social Work, 7(1), 57-71.

Humphries, B. (2004) 'An unacceptable role for social work: implementing immigration policy', British Journal of Social Work, 34(1), 93-107.

King, M. and Trowell, J. (1992) Children's Welfare and the Law. The Limits of Legal Intervention. London: Sage.

Laming, H. (2003) Inquiry into the Death of Victoria Climbié. London: The Stationery Office.

Madden, R. and Wayne, R. (2003) 'Social work and the law: a therapeutic jurisprudence perspective', Social Work, 48(3), 338-347.

Muttaqin, F. (2015). Early Feminist Consciousness and Idea Among Muslim Women in 1920s Indonesia. Jurnal Ilmiah Peuradeun, 3(1), 19-38.

Pawson, R., Boaz, A., Grayson, L., Long, A. and Barnes, C. (2003) Types and Quality of Knowledge in Social Care. London: Social Care Institute for Excellence.

Preston-Shoot, M. (2001) 'Regulating the road of good intentions: observations on the relationship between policy, regulations and practice in social work', Practice, 13(4), 5-20.

Reder, P., Duncan, S. and Gray, M. (1993) Beyond Blame. Child Abuse Tragedies Revisited. London: Routledge.

Tabrani. ZA. (2014). Islamic Studies dalam Pendekatan Multidisipliner (Suatu Kajian Gradual Menuju Paradigma Global). Jurnal Ilmiah Peuradeun, 2(2), 127-144.

Vohra, S. (2015). The Practice of Dowry in the Perspective of Hinduism In India. Jurnal Ilmiah Peuradeun, 3(3), 363-370.

Watkinson, A. (2001) 'Human rights laws: advocacy tools for a global civil society', Canadian Social Work Review, 18(2), 267-286. 